Original Research Article

\title{
A comparative study to assess the efficacy and safety of bepotastine and cetirizine in allergic rhinitis
}

\author{
A. T. Priyanka ${ }^{1}$, K. R. Mamatha ${ }^{1}$, G. M. Puttamadaiah ${ }^{2}$
}

\begin{abstract}
${ }^{1}$ Department of Pharmacology, ${ }^{2}$ Department of ENT, Bangalore Medical College and Research Institute, Bengaluru, Karnataka, India
\end{abstract}

Received: 04 August 2019 Accepted: 10 September 2019

*Correspondence to:

Dr. K. R. Mamatha,

Email: mamathashekar67@ yahoo.com

Copyright: (C) the author(s), publisher and licensee Medip Academy. This is an openaccess article distributed under the terms of the Creative Commons Attribution NonCommercial License, which permits unrestricted noncommercial use, distribution, and reproduction in any medium, provided the original work is properly cited.

\begin{abstract}
Background: Pharmacotherapy is the mainstay of allergic rhinitis and many caregivers use over-the-counter antihistamines. Bepotastine is a novel oral second generation non-sedative antihistamine and an effective treatment option for allergic rhinitis. The objectives of the present study were to evaluate the efficacy and safety of bepotastine versus cetirizine an over the counter drug.

Methods: A prospective, randomized, open-label, parallel-group study was conducted among 60 patients fulfilling the inclusion and exclusion criteria. Group A $(n=30)$ received tablet cetirizine $10 \mathrm{mg}$ once daily and Group B $(n=30)$ received tablet bepotastine $10 \mathrm{mg}$ once daily. Efficacy was assessed by mean change in total symptom score (TSS) which is the sum of total nasal symptom score and total ocular symptom score at the end of two weeks from baseline.

Results: At the end of two weeks of treatment, both groups showed statistically significant $(p<0.005)$ improvements from their baseline TSS. Mean TSS was reduced from $12.36 \pm 2.12$ to $4.2 \pm 1.66$ in group A and from $13.33 \pm 3.039$ to $3.033 \pm 1.40$ in Group B. Significant statistical difference in TSS was seen more in Group B than Group A ( $\mathrm{p}<0.005)$.

Conclusions: Both the groups showed a substantial therapeutic benefit in patients with allergic rhinitis, however bepotastine is more effective.
\end{abstract}

Keywords: Rhinitis, Cetirizine, Bepotastine

\section{INTRODUCTION}

Allergic rhinitis (AR) is a type 1 allergic disease of the nasal mucosa, characterized by a paroxysmal repetitive sneezing, watery rhinorrhoea, and nasal blockage with prevalence of $25 \%$ worldwide. ${ }^{1}$ Over the previous decades, the prevalence of allergic disorders has risen to epidemic proportions. As a result of high and increasing occurrence, its significant impact on quality of life, its association with multiple comorbidities, the considerable costs in terms of use of healthcare resources, school or work absenteeism and loss of productivity, the disease represents a major global health concern. ${ }^{2}$
Numerous classes of pharmacological agents are available for treatment of AR. Although not fully an ideal treatment, second-generation antihistamines exhibit many desirable properties and provide an effective means of symptomatic treatment for allergic rhinitis. ${ }^{3}$

Cetirizine, a $\mathrm{H}_{1}$ receptor antagonist that is available overthe-counter (OTC), has been shown to be well tolerated and effective in allergic rhinitis. ${ }^{4}$ In addition to its antihistaminic properties, cetirizine is considered to have broad anti-inflammatory effects, including the inhibition of leukocyte influx, the reduction of intercellular 
adhesion molecule 1 expression, the augmentation of interleukin 10 and interferon gamma production. ${ }^{4}$

Bepotastine, a novel second-generation antihistamine has recently become available for clinical use. Along with its antihistamine action, this drug suppresses eosinophilic migration to nasal mucosa and controls day time and night time triggers, hence has proven to be effective in allergic rhinitis. ${ }^{5}$

Nevertheless, the burden and consequences of AR are often underestimated by healthcare providers, patients and their environment. ${ }^{6}$ Too often, the disease is underdiagnosed and remains mis- or un (der) treated, which leads to uncontrolled symptoms affecting work, home and social life. The aim of this study was to add to the current knowledge regarding the efficacy and safety of cetirizine and bepotastine in treatment of AR.

\section{METHODS}

A prospective, open label, parallel group, comparative clinical study conducted at ENT OPD, attached to Bangalore Medical College and Research Institute, Bengaluru.

After obtaining clearance and approval from the Institutional ethics committee (reference no. BMCRI/PS/145/2018-19) and written informed consent, the study was carried out from November 2018 to May 2019 among 60 patients clinically diagnosed with moderate to severe allergic rhinitis of either sex, aged between 18-65 years. Patients with hypersensitivity to study medications, pregnant and lactating women were excluded.

Enrolled patients were randomly divided into two groups of 30 each and simple randomization was carried out using computer generated randomization sequence (www.randomization.com). Patients in Group A received tablet cetirizine $10 \mathrm{mg}$ per oral once daily and Group B received tablet bepotastine $10 \mathrm{mg}$ per oral once daily.
Demographic data, history of presenting illness, associated allergic disorders, concomitant medications, physical and clinical examination, nasal and ocular examination (nasal and ocular symptom scores), and details of the drug prescription were recorded at the baseline visit (visit 1). The patients received study medications for the period of two weeks irrespective of the symptom control and were followed up at the end of two weeks (visit 2). A deviation of \pm 2 days for follow-up was accepted. Study subjects were evaluated for nasal symptoms (nasal congestion, rhinorrhea, nasal itching, and sneezing) and ocular symptoms (itching or burning eyes, tearing or watering eyes, and eye redness) on a 4point scale. Efficacy was assessed by mean change in total symptom score (TSS) which is the sum of total nasal symptom score (TNSS) and total ocular symptom score (TOSS) at the end of the study. Safety was assessed by any adverse reactions reported by the patient as well as those observed by the physician.

Data was analyzed using descriptive statistics. Paired and unpaired student $\mathrm{t}$ tests were used to compare the results within the group and between the groups respectively. $p$ value $<0.05$ is considered statistically significant.

\section{Sample size}

Based on a study conducted by Kimihiro et al sample size of 60 was calculated to detect a difference in symptom scores of $0.070 \pm 0091$ at $90 \%$ power and $5 \%$ significance level under two tailed tests of significance. ${ }^{7}$

\section{RESULTS}

Sixty participants were randomized into two study groups using computer generated randomization sequence in 1:1 ratio. These 60 participants were comparable at baseline with respect to age, sex and symptom scores (Table 1). The average age of study participants was 29.7 which included 21 males and 39 females showing female preponderance.

Table 1: Demographic details.

\begin{tabular}{|c|c|c|c|c|}
\hline \multicolumn{2}{|c|}{ Characteristics } & Cetirizine group $(\mathrm{n}=30)$ & Bepotastine group ( $n=30)$ & $P *$ value \\
\hline \multicolumn{2}{|c|}{ Mean age in years (SD) } & $29.3(10.10)$ & $30.06(8.30)$ & 0.75 \\
\hline \multicolumn{2}{|c|}{ Sex } & & & 0.58 \\
\hline \multicolumn{2}{|l|}{ Male } & 12 & 9 & \\
\hline \multicolumn{2}{|l|}{ Female } & 18 & 21 & \\
\hline \multirow{4}{*}{$\begin{array}{l}\text { Occupation } \\
\text { history }\end{array}$} & Students & 9 & 12 & \multirow{4}{*}{0.45} \\
\hline & Home makers & 7 & 10 & \\
\hline & Outdoor workers & 9 & 5 & \\
\hline & Others & 5 & 3 & \\
\hline \multicolumn{2}{|c|}{ Family history } & $14(46 \%)$ & $12(40 \%)$ & \multirow{4}{*}{0.59} \\
\hline \multicolumn{2}{|c|}{ History of asthma } & $5(16.66 \%)$ & $7(23 \%)$ & \\
\hline \multirow{2}{*}{ Habits } & Smokers & 2 & 3 & \\
\hline & Non-smokers & 28 & 27 & \\
\hline
\end{tabular}

\footnotetext{
$*$ : $\mathrm{p}$ value $<0.05$ shows significant difference.
} 


\section{Efficacy analysis}

\section{Change in TSS}

TSS was assessed at baseline and the end of 2 weeks for all the participants. Baseline mean TSS for Group A and Group B was $12.36 \pm 2.12$ and $13.33 \pm 3.03$ respectively, which was comparable (Figure 1). At the end of the treatment mean TSS reduced to $4.2 \pm 1.66$ in Group A and $3.033 \pm 1.40$ in Group B which was statistically significant from baseline (Figure 2). The change in between the study groups was statistically significant (Table 2).

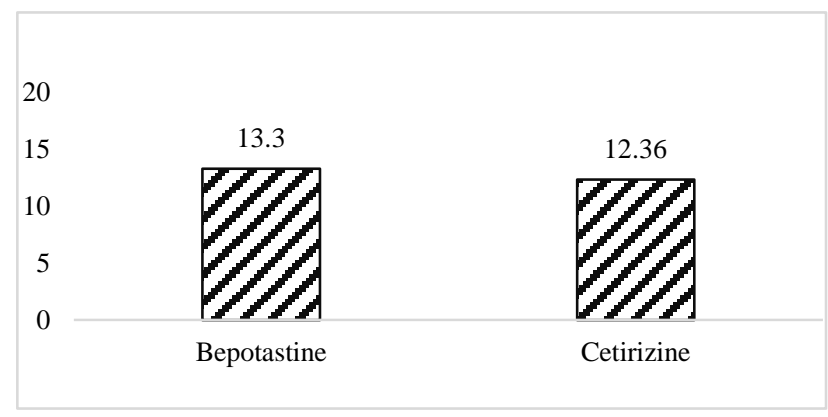

Figure 1: Baseline TSS for both treatment groups.

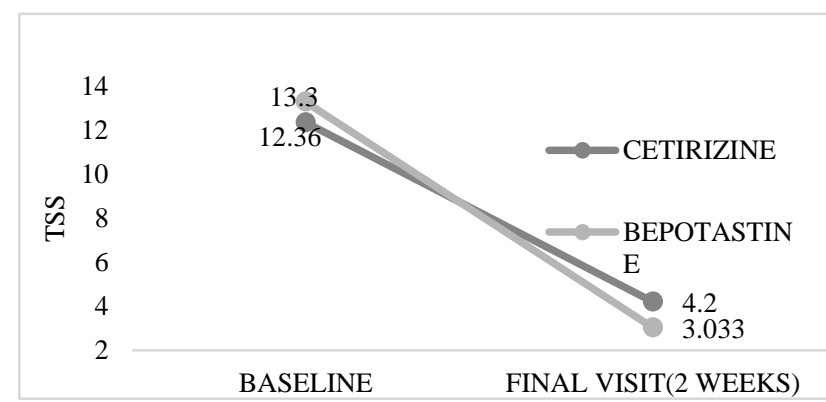

Figure 2: TSS between the two study groups at baseline and end of two weeks.

\section{Change in TNSS}

TNSS was evaluated at baseline and the end of 2 weeks for all the participants. Baseline TNSS for Group A and Group B was $9.2 \pm 1.54$ and $9.13 \pm 1.56$ respectively, which was comparable. At the end of 2 weeks of treatment, TNSS was 3.26 \pm 1.28 in Group A and 2.41 \pm 1.08 in Group B. The changes from the baseline in both the study groups were statistically significant (Figure 3). However, TNSS in Group B reduced to a greater extent than Group A which was statistically significant (Table 2 and 3 ).

Table 2: Baseline efficacy parameters.

\begin{tabular}{|c|c|c|c|}
\hline & $\begin{array}{l}\text { Cetirizine } \\
(\mathbf{n}=\mathbf{3 0})\end{array}$ & $\begin{array}{l}\text { Bepotastine } \\
(\mathbf{n = 3 0})\end{array}$ & P value* \\
\hline TSS & $12.36 \pm 2.12$ & $13.33 \pm 3.03$ & 0.18 \\
\hline TNSS & $9.2 \pm 1.54$ & $9.13 \pm 1.56$ & 0.86 \\
\hline TOSS & $3.23 \pm 1.04$ & $4.41 \pm 0.59$ & 0.058 \\
\hline
\end{tabular}

*: $\mathrm{p}$ value $<0.05$ shows significant difference.
Comparison of symptom scores at baseline between the groups.

Table 3: Final efficacy parameters at the end of two weeks.

\begin{tabular}{|llll|}
\hline & $\begin{array}{l}\text { Cetirizine } \\
(\mathbf{n}=30)\end{array}$ & $\begin{array}{l}\text { Bepotastine } \\
(\mathbf{n}=30)\end{array}$ & $\begin{array}{l}\mathbf{p} \\
\text { value* }^{*}\end{array}$ \\
\hline TSS & $4.2 \pm 1.66$ & $3.033 \pm 1.40$ & 0.048 \\
\hline TNSS & $3.26 \pm 1.28$ & $2.41 \pm 1.08$ & 0.041 \\
\hline TOSS & $0.93 \pm 0.78$ & $0.71 \pm 0.80$ & 0.21 \\
\hline
\end{tabular}

*: p value $<0.05$ shows significant difference.

Comparison of symptom scores at the end of the study between the groups.

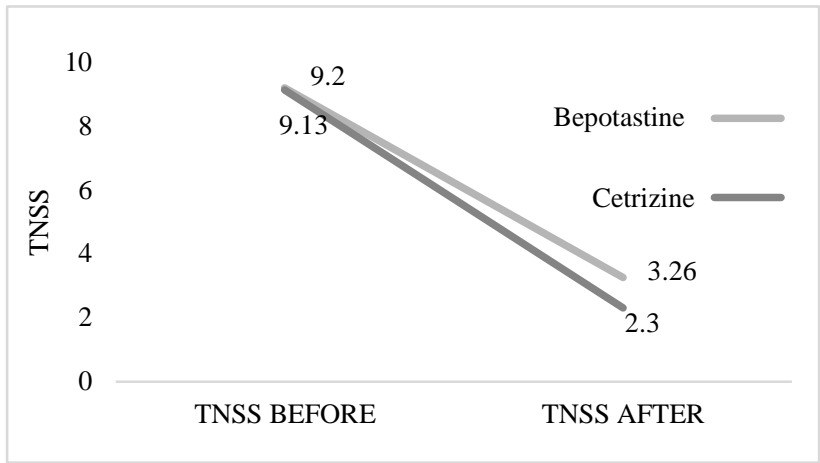

Figure 3: TNSS between the two study groups at baseline and end of two weeks.

\section{Change in TOSS}

Baseline TOSS for Group A and Group B was 3.23 \pm 1.04 and $4.41 \pm 0.59$, respectively, which was comparable. At the end of 2 weeks of treatment, TOSS was $0.93 \pm 0.78$ in Group A and $0.71 \pm 0.80$ in Group B (Figure 4). This reduction in TOSS was comparable in between the study groups (Table 2 and 3 ).

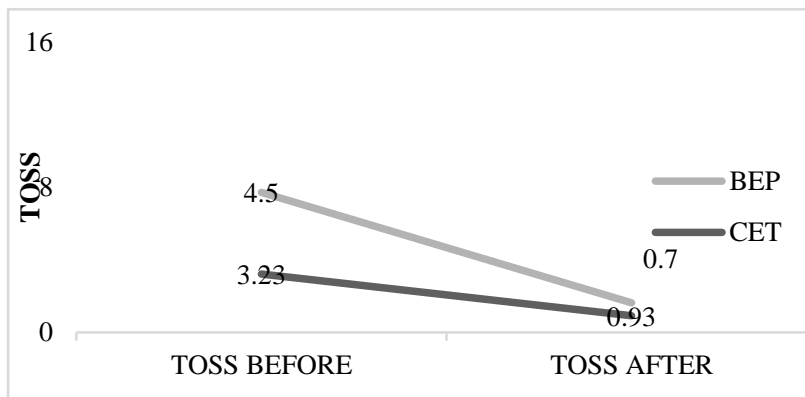

Figure 4: TOSS between the two study groups at baseline and end of two weeks.

\section{Safety analysis}

During the study period, we only encountered mild adverse drug reactions associated with both groups which did not require discontinuation of medication. The most 
common adverse effect was sedation which was more in cetirizine group. No serious adverse events reported (Table 4).

\section{Table 4: Safety profile.}

\begin{tabular}{|c|c|c|}
\hline \multirow{2}{*}{ Adverse effect } & $\begin{array}{l}\text { Bepotastine } \\
\text { group }(n=30)\end{array}$ & $\begin{array}{l}\text { Cetirizine } \\
\text { group }(n=30)\end{array}$ \\
\hline & $\mathbf{N}(\%)$ & $\mathbf{N}(\%)$ \\
\hline Somnolence & $4(13.33)$ & $7(23.33)$ \\
\hline Dizziness & $3(10)$ & $4(13.33)$ \\
\hline Headache & $1(3.33)$ & $1(3.33)$ \\
\hline
\end{tabular}

\section{DISCUSSION}

Currently prevalence of allergic rhinitis is increasing and good epidemiologic studies suggest that 20 to $30 \%$ of adults and up to $40 \%$ of children are affected. ${ }^{8}$ Global climate changes leading to elevated levels of carbon dioxide increased plant productivity and increase in airborne pollen may explain the increasing prevalence. ${ }^{9}$ Symptoms can have significant negative impact on the patients' quality of life, often interfere with sleep and contribute to poor performance at work. Choosing correct treatment with minimal side effects still is a challenge for physicians.

In the past, allergic rhinitis was considered to be a disorder localized to the nose and nasal passages, but current evidence indicates that it may represent a component of a systemic airway disease involving the entire respiratory tract. ${ }^{10} \mathrm{IgE}$ molecule has a prominent role in pathogenesis of allergic rhinitis, and adhering to a special receptors on the surface of mast cells and basophils results in degranulation and release of multiple mediators. ${ }^{11}$ Histamine is one of these mediators that induces mucosal secretion, vascular dilation, increase vascular permeability, tissue edema, itching and sneezing. ${ }^{12}$ In addition to allergen avoidance, suggested treatments for $\mathrm{AR}$ include $\mathrm{H} 1$ receptor antagonists (antihistamines), corticosteroids, immunotherapy, intranasal saline solutions and leukotriene receptor antagonists. $^{13}$

Oral antihistamines frequently are used as OTC; therefore, it is important the physician should be sure the patient receives correct drug in enough dose with minimal side effects. Although the first-generation $\mathrm{H} 1$ antihistamines were developed and widely used clinically from the mid-1940s to the late 1970s; a comparably lower efficacy and association with particularly sedative and anticholinergic side effects have restricted their usefulness and subsequently led to the development of the more efficacious and safer second-generation antihistamines. $^{14}$

Second-generation antihistamines are preferable in these disorders as they have got the dual mode of action both as histamine antagonist and mast cell stabilizer. They also exert significantly less sedation as compared to the firstgeneration antihistamine while maintaining a higher efficacy. ${ }^{15}$ Hence, the focus of this study was to evaluate the use of cetirizine and bepotastine in management of AR.

In the present study the baseline data show no significant difference between the study groups with respect to demographic parameters. This proves the homogeneity of the study patients in the two groups. The efficacy of the study drugs was assessed by the total nasal symptom score, total ocular symptom score and total symptom score. Both the study drugs were administered in a dose of $10 \mathrm{mg}$ once daily. At the end of two weeks there was a significant change in TNSS and TOSS parameters in both the study groups from the baseline. However, bepotastine had a greater reduction in total symptom score when compared to cetirizine and was found to be statistically significant $(\mathrm{p}=<0.05)$ as shown in Figure 2.

The results of our study have been in accordance with past study done by Deshmukh et al on "efficacy and safety of bepotastine, a newer 2nd generation antihistamine, compared to fexofenadine in allergic rhinitis". ${ }^{16}$ Bepotastine in twice daily dose regimen in adult population has been the focus of numerous clinical trials in patients suffering from allergic rhinitis.

Oral bepotastine is a highly selective second-generation histamine $\mathrm{H} 1$ receptor antagonist and has shown long lasting, dose-dependent antihistaminic and antiallergic activity in vitro and in vivo. H1-receptor blocking is not the only anti-allergic activity of bepotastine, it has inhibitory effects on eosinophilic inflammation in the respiratory tract and peripheral blood. Furthermore, bepotastine can stabilize mast cell function, inhibit IL-5 (Interleukin-5) production, and inhibit the activity of leukotrienes B4 and D4.

Both the drugs were well tolerated. Sedation, dizziness and headache were common side effects. Over all adverse event rate has been very low showing good tolerance for bepotastine compared to cetirizine. Bepotastine has very low affinity to other cell receptors such as histamine H3, $\alpha 1-, \alpha 2-$ and $\beta$-adrenergic, serotonin, muscarinic, and benzodiazepine receptors, which causes adverse effects to be few and uncommon. ${ }^{5}$ By reviewing the currently available literature and the results of the present study bepotastine which is now available in India seems to be a promising agent to combat allergic rhinitis due to its nonsedating profile, lesser to no adverse effects and dual mode of action on histamine and other inflammatory mediators.

\section{CONCLUSION}

In our study, both the treatment groups demonstrated significant therapeutic benefit in patients with AR. However, our data suggested that the efficacy of bepotastine, a novel second-generation antihistamine was 
significantly more than cetirizine with respect to the TSS and TNSS, although there was no significant difference in TOSS. Further trials are needed to prove its use in the Indian population in different allergic conditions.

\section{ACKNOWLEDGEMENTS}

Authors would like to thank Head of the department and faculty of Department of Pharmacology and ENT for their guidance and support in completing their study.

\section{Funding: No funding sources}

Conflict of interest: None declared

Ethical approval: The study was approved by the Institutional Ethics Committee

\section{REFERENCES}

1. Varshney J, Varshney H. Allergic rhinitis: an overview. Indian J Otolaryngol Head Neck Surg. 2015;67(2):143-9.

2. Kankaanranta H, Kauppi P, Tuomisto LE, Ilmarinen P. Emerging comorbidities in adult asthma: risks, clinical associations, and mechanisms. Mediator Inflammat. 2016;2016:3690628.

3. Recto MT, Gabriel MT, Kulthanan K, Tantilipikorn $\mathrm{P}$, Aw DC, Lee TH, et al. Selecting optimal secondgeneration antihistamines for allergic rhinitis and urticaria in Asia. Clin Mol Allerg. 2017;15:19.

4. Cheng KC, Hsu JY, Fu LS, Chang WC, Chu JJ, Chi CS. Influence of cetirizine and loratadine on granulocyte- macrophage colony-stimulating factor and interleukin-8 release in A549 human airway epithelial cells stimulated with interleukin-1beta. J Microbiol Immunol Infect. 2006;39(3):206-11.

5. Godse K, Kumari N. Bepotastine besilate: a novel anti-histamine. Indian J Drugs Dermatol. 2017;3:648.

6. Okubo TFK. Effectiveness of second-generation antihistamine for the treatment of morning symptoms observed in patients with perennial allergic rhinitis: comparison study of bepotastine besilate versus olopatadine hydrochloride. Otorhinolaryngol. 2015;05(2):1000185.

7. Nathan RA. The burden of allergic rhinitis. Allergy Asthma Proc. 2007;28(1):3-9.

8. Hoyte FCL, Nelson HS. Recent advances in allergic rhinitis. F1000Res. 2018;7: F1000 Faculty Rev-1333.

9. Lalitha A, Mamatha KR, Puttamadaiah GM. Azelastine hydrochloride nasal spray and its combination with fluticasone propionate in the management of allergic rhinitis- a comparative study. Nat J Physiol Pharm Pharmacol. 2019;9(5):356-60.

10. Small P, Keith PK, Kim H. Allergic rhinitis. Allergy Asthma Clin Immunol. 2018;14(2):51.

11. Galli SJ, Tsai M. IgE and mast cells in allergic disease. Nat Med. 2012;18(5):693-704.

12. Rotiroti D, De Sarro GB, Musolino R, Nistico G. 1983. A new model of experimental epilepsy: the cephazolin-induced epilepsy. In: Nistico G, Di Perri R, Meinardi H, eds. Epilepsy, an update of research and therapy. New York: Alan R. Liss, Inc.; 129-144.

13. Yanez A, Rodrigo GJ. Intranasal corticosteroids versus topical $\mathrm{H} 1$ receptor antagonists for the treatment of allergic rhinitis: a systematic review with meta-analysis. Ann Allergy Asthma Immunol. 2002;89(5):479-84.

14. Zhang L, Cheng L, Hong J. The clinical use of cetirizine in the treatment of allergic rhinitis. Pharmacol. 2013;92:14-25.

15. Canonica GW, Blaiss M. Antihistaminic, antiinflammatory, and antiallergic properties of the nonsedating second-generation antihistamine desloratadine: a review of the evidence. World Allergy Organ J. 2011;4(2):47-53.

16. Deshmukh S, Narayanan V, Bhargava A. Efficacy and safety of bepotastine, a newer 2 nd generation antihistamine, compared to fexofenadine in allergic rhinitis. World J Pharm Med Res. 2018;4(9):186-90.

Cite this article as: Priyanka AT, Mamatha KR, Puttamadaiah GM. A comparative study to assess the efficacy and safety of bepotastine and cetirizine in allergic rhinitis. Int J Basic Clin Pharmacol 2019;8:2304-8. 